Ilmenau University of Technology

Institute of Economics

Ilmenau Economics Discussion Papers, Vol. 19, No. 86

Are Restrictions of Competition by Sports Associations Horizontal or Vertical in Nature?

Oliver Budzinski, Stefan Szymanski

March 2014

Institute of Economics

Ehrenbergstraße 29

Ernst-Abbe-Zentrum

D-98 684 Ilmenau

Phone 03677/69-4030/-4032

Fax 03677/69-4203

http://www.wirtschaft.tu-ilmenau.de

ISSN 0949-3859 


\title{
Are Restrictions of Competition by Sports Associations Horizontal or Vertical in Nature? ${ }^{1}$
}

\author{
Oliver Budzinski ${ }^{\#}$ \& Stefan Szymanski
}

\begin{abstract}
In this paper, we discuss from an economic perspective two alternative views of restrictions of competition by sports associations. The horizontal approach views such restrictions as an agreement among the participants of a sports league with the sports association merely representing an organization executing the horizontal cooperation. In contrast, the vertical approach views the sports association as being a dominant upstream firm enjoying a monopoly position on the market stage for competition organizing services, an important input for the actual product - the sports game. Taking the recent financial fair play (FFP) initiative by UEFA (the Union of European Football Associations) as an example, we demonstrate that the different views lead to different assessments of restrictive effects and, thus, matter for competition policy decisions. The economic story of the potential restrictive effect of FFP on players' and player agents' income may fit more plausibly to the horizontal approach, whereas the potentially anticompetitive foreclosure and deterrence effects of FFP may be economically more soundly reasoned by taking the vertical view.
\end{abstract}

Keywords: European competition policy, sports economics, financial fair play, horizontal agreements, vertical restrictions, European football, antitrust

JEL-Classification: K21, L41, L42, L44, L83

\footnotetext{
${ }^{1}$ We thank Stephen F. Ross for helpful comments.

\# Professor of Economic Theory, Institute of Economics, Ilmenau University of Technology, Ehrenbergstr. 29, D-98693 IImenau, Germany, Email: oliver.budzinski@tu-ilmenau.de.

* Professor of Sport Management, School of Kinesiology, University of Michigan, 3118 Observatory Lodge, 1402 Washington Heights, Ann Arbor, MI 48109-2013, stefansz@umich.edu.
} 


\section{Introduction}

Professional team sports organizations in the US operate under economic restraints that are horizontal in character. For example, Major League Baseball (MLB) is an American sports league consisting of 30 teams whose owners fix the rules of the game and agree among themselves a number of restraints, including rules that limit economic competition, either by means of revenue sharing, collective selling or (in the context of collective bargaining with a players' union) restrictions on the ability to recruit and retain players. The clubs appoint a Commissioner with extensive powers to regulate the clubs, but the Commissioner can also be dismissed by a vote of the owners. Under competition law, the restraints employed in MLB are clearly horizontal - they are agreements entered into by the owners of the competing teams. ${ }^{2}$ The same can be said of the other American major league sports as well as of the National Collegiate Athletic Association (NCAA). ${ }^{3}$ Moreover, the autonomy of the professional major league sports is enshrined in statute. The Ted Stevens Amateur Sports Act (1998) specifies that the US Olympic Committee can organize governing bodies for individual sports, but only with jurisdiction over amateur sport. ${ }^{4}$

In Europe the situation is very different. Sports governing bodies which claim jurisdiction over both amateur and professional competition have existed at the national level since the $19^{\text {th }}$ century. These national associations have extensive powers to set the rules of competition at all levels and there is typically a complex process by which leadership figures are elected. Unlike the American major leagues, the professional league clubs in Europe do not have complete discretion to set their own rules (even if they are capable of exerting influence). It is questionable whether restraints imposed by the official rules of the national associations should be treated as horizontal in nature - they are not merely agreements entered into by owners of the teams that have to follow these rules. They are, at least in part, vertical agreements: they are agreements between undertakings at different points in the production chain, in a sense that we will make clear. Due to the nature of the organization of sports, these vertical agreements typically involve an entity in a dominant position.

If correct, this analysis has important consequences, since hitherto restraints imposed on sporting competition have been treated as horizontal agreements and vertical aspects have not been considered. ${ }^{5}$ Our analysis was prompted by the financial regulatory constraints known as Financial Fair Play (FFP) which were designed by UEFA, the European governing body of football, and enter into full force in the summer of

${ }^{2}$ See explicitly the US Supreme Court in NCAA v Board of Regents 468 U.S. 85 (1984).

${ }^{3}$ As well as MLB the majors consist of the National Football League (NFL), The National Basketball Association (NBA), the National Hockey League (NHL) and Major League Soccer (MLS). In practice most restraints in the majors are not subject to antitrust scrutiny because they are embedded on a collective bargaining agreement.

${ }^{4} 36$ U.S.C. Sec. 220501 et seq.

${ }^{5}$ There are some notable exceptions when it comes to sports associations (in other sports than European football) that are not member associations. For instance, the antitrust case against the Fédération International d'Automobiles (FIA) involved some vertical considerations even though it predominantly focused on horizontal issues (deterrence on the market of promoters of motor racing series). See Budzinski (2012: 55-58) for a recent discussion. 
2014. However, the fundamental point we are making here also applies more generally to cases of rule-setting by sports associations. The FFP-restraints give UEFA the power to prevent clubs from entering competitions that it organizes on financial grounds. In particular, these rules concern not just solvency, but the way in which the club is funded and the ways in which the owners use their funds.

Prior to imposing these rules UEFA conducted an extensive consultation process which included, but was not restricted to, the clubs which are subject to these rules. Most of the clubs have stated publicly their support for FFP, but it is not clear on the extent to which this support was elicited only once it had become clear that the rules would be passed anyway. At least one league organization, the English Premier League, publicly expressed opposition at the time. Given that the decision to adopt FFP was not restricted to the clubs to whom it will apply, and given that the process of developing the rules was both initiated and executed by UEFA, we believe that this is clear evidence of a vertical dimension of the restraints.

Our analysis in this paper will be developed as follows: in the next section we briefly outline the general problem of competition law and sports leagues. Section 3 considers horizontal approach in more detail while section 4 introduces the vertical approach. Section 5 discusses the economic implications of the analysis and section 6 concludes. Since our analysis has been motivated by FFP we will focus throughout on the application of our analysis to this case.

\section{Competition Law, Sports and Sports Associations}

Sports are clearly a special case when it comes to competition law. For sporting competition to exist, there must be coordination among competitors, at the very least to agree the rules of the game. In the case of team sports played in front of thousands of spectators and watched by millions on TV and other devices, each team requires the co-operation of the other team just to make the "product". Given that a per se rule against co-operation among sporting rivals is not feasible, the question as to whether competition law is violated requires a rule of reason analysis. Historically, the courts in Europe have attempted to draw a distinction between cases involving purely sporting rules, as opposed to those which have an economic or business dimension, on the view that the former would clearly be exempt from antitrust scrutiny, while the latter can potentially be restrictive of competition. For example, rules concerning the size of a football are purely sporting and exempt, while agreements to sell broadcast rights collectively are primarily economic and thus not exempt. However, even in the latter case the restraint may survive if there are benefits to consumers. This approach is problematic since any rule can potentially have a commercial as well as a sporting dimension (Weatherill 2006), an insight acknowledged in the landmark Meca-Medina case. In 2007 the Commission outlined a three step procedure for assessing whether sporting rules are consistent with the competition law: ${ }^{6}$

\footnotetext{
${ }^{6}$ See European Commission (2007) for details and Budzinski (2012) for an assessment.
} 
1. Are the competition law rules applicable (primarily, does the EU have jurisdiction and is there a restriction of competition or an abuse of a dominant position)?

2. Does the rule infringe the law (Article 101 TFEU which prohibits anti-competitive agreements, or Article 102 TFEU which prohibits abuse of a dominant position)? The sporting rule does not infringe the law if the rule is in pursuit of a legitimate objective, the restrictive effects are inherent to the pursuit of that objective and proportionate to it.

3. Is the rule exempt? Under Article 101 a rule can be exempt if pro-competitive effects outweigh anti-competitive effects, and under Article 102 an infringement can be exempt if there is an objective justification for it.

A notably popular defense of rules adopted by sports organizations in the EU, and to a lesser extent also in the US, has been the claim that a restraint may enhance competitive balance. The competitive balance defense proceeds by claiming that fans will lose interest in a sport unless each of the competitors has a reasonable chance to win, and that this chance requires a relatively even distribution of resources, which can be fostered by a restraint (such as collective selling of broadcast rights, so long as the distribution formula is considered sufficiently equitable). ${ }^{7}$ Such agreements are usually negotiated through some kind of association. As mentioned in the introduction, major leagues in the US are associations of the teams that play in the league which have absolute powers to make agreements among their members. Sports leagues in Europe also have their own member associations such as the Premier League in England or the Deutsche Fußball Liga (DFL, German Football League), but these are not sovereign organizations. Instead they are members of national (and sometimes regional) associations that represent all clubs within their jurisdiction, from amateur to professional, men and women, youth sport and sometimes sport in schools. $^{8}$

The typical membership unit of an association is the club, but each club may have different voting rights depending on its status. In addition these organizations can have quite complex decision making structures. From our perspective, the key point is that the governing body will take account interests of those organizations directly affected by the rules. The analysis of governing bodies is complicated by the variety of functions they undertake. Thus their primary function may be considered to be the making and enforcing of rules, managing disciplinary procedures and arbitrating disputes, but in addition they often function as organizers of competitions in their own right, as well as promoters of development initiatives at youth and community levels. For most fans their main interest in the national association is as the organizer of the national team. UEFA, the association of the European governing bodies also runs the UEFA Champions League, one of the most prestigious club competitions in the world which generates around $\$ 1$ billion per year in broadcast income. ${ }^{9}$ These

${ }^{7}$ See Szymanski (2003) for an economic analysis of this defense.

${ }^{8}$ The reason that this happened in Europe but not in the US is interesting and relates to the early development of football in England and baseball in the US; see Szymanski and Zimbalist (2005, ch. 2) for an account.

${ }^{9}$ This competition, originally known as the European Cup, was in fact the main reason for the creation of UEFA back in 1955. Whereas the national associations are much older, and FIFA has existed as 
rights are sold by UEFA and the lion's share of the money is distributed to the clubs in the form of prize money, but UEFA also gives some money to the national associations and funds its own activities out of the proceeds. ${ }^{10}$

Unlike the release of players for national competition, the relationship between UEFA and larger clubs regarding the organization of European-wide club competitions can be viewed as largely cooperative, since they share an interest in the maximizing the commercial value of the competition. At the same time there are conflicts. On several occasions in recent decades (notably in the late 1980s and 1990s) the big clubs have talked about the idea of creating their own Superleague so as not to share income with the lesser clubs and with UEFA itself (e.g. Hoehn \& Szymanski 1999). In the 1990s some of these clubs created their own lobbying association within UEFA (called the G14) to represent their interests collectively. This was disbanded in 2008 and now the negotiating position of all clubs is represented by the European Clubs Association (ECA).

An important development of the relationship between football clubs and governing bodies is the creation of licensing procedures. Traditionally the relationship between clubs and national associations differed considerably by country. In most European countries membership of an association had to be registered by law, and the relationship between club and association is viewed as one between licensee and licensor. In the anglo-saxon tradition this was not the case, and there was little or no monitoring of member clubs by the governing bodies. This different approach explains why, for example, the German Football Association was always able to put a precise number on the number of players participating in the Association, while to the present day the English Football Association can only provide a rough estimate.

However, even in England, the football authorities, often pressured by government, have been required to take a stricter view of governance in relation to larger clubs when dealing with issues such as safety at stadiums. European football competition has traditionally operated on the basis of sporting merit - all clubs are eligible to enter competition, and through the system of promotion and relegation (on sporting merit) can ascend (or descend) the sporting ladder. In more recent times clubs have had to face non-sporting conditions for eligibility, of which those concerning safety are only the most obvious.

In 1999 UEFA decided to embark on a system of club licensing for clubs entering UEFA competitions. According to UEFA, initially the purpose was to explore the possibility of creating a salary cap, but it was soon decided that this could not be done without first creating a legal framework (UEFA 2008: 8). The rules of the licensing

the world governing body since 1904, the more recent creation of UEFA reflects its more uncertain status. It was really only in the 1990s, when European football started to generate significant revenues and became a more important focus for competition policy analysis (e.g. the Bosman judgment of 1995 which ensured free movement of players within the EU) that UEFA's role as a coordinator of responses to EU initiatives came to the fore. It was also then that its competitions started to generate more revenue and the negotiation of broadcast rights was shifted from the individual clubs to a system of collective selling.

${ }^{10}$ UEFA organizes other less lucrative club competitions, and in recent years has restructured to create the Europa League. 
system are laid down by UEFA, and the award of the licenses is overseen by the national associations so as to bring "member associations closer to their clubs". Initially the licensing system laid down rules relating to sporting development (youth training), infrastructure (stadiums), personnel and administration (key posts to be filled), legal (documentation) and financial issues. The financial requirements were for the provision of periodic audited financial statements, and that clubs should have no "overdue payables" to other clubs or players. These requirements were applied from the 2004/05 season, and extended in 2008/09 season to include no overdue payment to tax authorities and provision of budget forecasts. In 2009 UEFA also announced the introduction of Financial Fair Play.

The regulations of Financial Fair Play specify that any club that wishes to take part in UEFA's two main competitions, the Champions League and Europa League, must obtain a license from their national association certifying that they meet certain criteria. The key criteria are

(i) no overdue payables, i.e. a club must be fully up to date with payments to creditors, and

(ii) break-even, i.e. a club must be able to demonstrate that "relevant" income balances with "relevant" expenditure. For these purposes the balance of income and expenditure are calculated over a three year period, and the balance is subject to an acceptable deviation of $€ 5$ million. Moreover, there is a transitional period to 2018 during which larger deviations are permitted.

The break-even constraint is complex, since allowable income and expenditures are defined in great detail. "Relevant" or "football" income is broadly defined as income from ticket sales, merchandising, broadcasting rights and sponsorship. Football expenditure is broadly defined as wage and transfer spending on players. They do not coincide with simple accounting definitions and a club could in theory declare an accounting profit while failing to meet break-even or declare an accounting loss but meet break-even. ${ }^{11}$

In order to demonstrate the differences of the horizontal and the vertical approach to restrictive rules set by sports associations, we examine two potentially anticompetitive stories of FFP:

- FFP regulations lead to a reduction of player salaries via the reduction in total investment in talent (due to the narrowing of possible club income to UEFAdefined "relevant", i.e. revenue-based, income) and, thus, impose a significant restraint on the player market.

${ }^{11}$ Actually, a club could in theory meet the break-even requirement and go into administration (e.g. because unable to meet future debt repayments because of large expenditures on youth programs and stadium infrastructure), whilst another club could fail to meet break-even but be completely solvent due to 'non-football' income. For economic analyses of FFP see generally Vöpel (2011), Madden (2012), Sass (2012), Franck (2013), Budzinski (2014), Maxcy (2014), Peeters \& Szymanski (2014), Szymanski (2014). 
- FFP regulations favor incumbent clubs that are dominant in UEFA competitions at the expense of less established clubs that might seek to fund a competitive challenge out of 'non-football' revenues, for instance, provided by a wealthy owner (sometimes called "sugar daddies"; e.g. Franck 2013). ${ }^{12}$ This may limit the competitive attractiveness of the Champions League as incentives to compete maybe reduced and ultimately the best players might move to other parts of the world where there are fewer restraints. Thus, FFP may lessen the entrepreneurial risk of investment while reducing the intensity of competition, decreasing level of talent and so harming consumer welfare in the long run.

Note that we do not provide an analysis whether these anticompetitive concerns of FFP are justified or not. Instead, we show how their assessment requirements and analysis framework depends on whether the horizontal or the vertical approach is chosen.

\section{The Horizontal View and Its Problems}

\section{(a) Basic Approach}

From one perspective, regulatory action by the market-internal governing body (i.e. the sports association) constitutes a form of horizontal cooperation among the participants of the league or championship. This reasoning draws from the observations that (i) sports associations are membership organizations and (ii) there must necessarily be cooperation among the competitors within a sports league or championship regarding the rules of the game. In other words, membership-based sports associations carrying out regulatory activities constitute a horizontal cartel among the participants of the sporting competition since the association acts as an agent of the participants (i.e. it represents something like a "syndicate company" who organizes the cartel). There is some basis for this perspective in the historical evolution of many sports leagues or championships (both in Europe and elsewhere), where sporting competitors managed the necessary cooperation by creating an association as a regulatory body and participated in the operations of this body. The distinctive feature is that the participants "own" the sports association in the sense that its rules and regulations are ultimately subject to an Assembly of all members who are able to vote on changes to its constitution and thereby determine it activities. Many sports in Europe possess such a structure in the sense that athletes are (voting) members of clubs that are (voting) members of local associations that are (voting) members of national associations that are (voting) members of supranational associations. The European Commission calls this the monopolistic pyramid structure of sports governance (Kienapfel \& Stein 2007: 7). In the case of individual sports, the pyramid membership chain starts with the athletes who are the sporting competitors, in the case of team sports it is the clubs that represent direct competitors in the league.

\footnotetext{
12 This entails the corresponding case where a team that has fallen back, e.g. due to a series of bad decisions on players and coaches, seeks to employ non-revenue based investments in order to catch up again.
} 
The competition policy consequence of the horizontal view is that regulatory activities by such sports associations fall under the rules for horizontal cartels (inter alia, Lindholm 2010: 198-200 with reference to the respective court judgments). According to this view, they constitute agreements among undertakings and associations of undertakings. In the European Union this includes the general cartel prohibition (Art. 101 (1) TFEU) and conditions for exemptions (Art. 101 (3) TFEU). Note that this does not necessarily imply that such regulatory activities are prohibited per se in the EU. Following up on a judgment of the European Court of Justice ${ }^{13}$, the European Commission has outlined the sports-specific conditions for a regulatory activity being exempted from the cartel prohibition (the enacted rule pursues a legitimate objective, its restrictive effects are inherent to this objective and proportionate to it, as described in section 2). In addition, the general conditions for receiving an exemption from the cartel prohibition apply (benefit to consumers, allocative efficiency, promotion of technological progress, no less-restrictive alternative available, and no significant harm to competition; Art. 101 (3) TFEU). Any rule-making activity of a sports association that fulfills those conditions can be carried out without intervention from the Commission or national competition authorities. Regulatory activities that do not completely fulfill these conditions may be allowed under conditions and obligations or else are prohibited.

\section{(b) Application to FFP}

In the case of UEFA's licensing systems or financial fair play regulations, the horizontal view would state that UEFA is an agent of the clubs participating in the Europeanlevel club competitions like the UEFA Champions League since UEFA's shareholders are national football associations. These national football associations either directly consist of clubs as their voting members (like in Denmark) or indirectly via regional football associations that then are constituted by club memberships (like in Germany or France). Thus, at the end of the day, it is the football clubs themselves that through their agents in form of the pyramid of associations - define and set licensing and financial fair play rules. Consequently, in the horizontal view, FFP would constitute a horizontal agreement among the football clubs participating in UEFA's tournaments (Lindholm 2010). In the course of their cooperative effort to set the rules of the game, the sporting competitors have colluded to restrict their investment behavior.

What does that imply for our two exemplary anticompetitive stories? With respect to the salary restriction effect, Lindholm (2010: 198-200) argues that the financial fair play regulations constitute a monopsonistic agreement that effectively represents a cartel of clubs (and their associations) on the market for talent that eventually restricts player wages through its deflating effect on clubs' total expenses (or the growth of it, respectively). Since the investment behavior is an important element of

\footnotetext{
${ }^{13}$ In its landmark Meca-Medina judgment, the ECJ has ruled that anti-doping rules issued by a sports association (here: the swimming association FINA) qualify as action by a cartel that is subject to Art. $101 \mathrm{TFEU}$, albeit, in the case in question, a cartel where it is justified to provide an exemption from the general cartel prohibition. See Case C-519/04P, Meca Medina v. Commission, ECR 2006, I-6991.
} 
the horizontal competition among the clubs (for talent but also for winning percentages, for prize money, etc.), this horizontal agreement is definitely restrictive in economic terms. Through FFP, the clubs are improving their profitability at the expense of the players.

Viewed as a restraint agreed among competitors, UEFA might argue that the rules of FFP fall outside the scope of the law because the objective is legitimate. UEFA's own regulations describe the objectives of FFP in terms of transparency, credibility, protection of creditors, discipline and rationality, responsibility and sustainability ${ }^{14}$. While these objectives might seem uncontroversial, it is a much more difficult question whether restrictions of clubs' investment and spending behavior are inherent to that objective. This would require establishing that unrestrained economic competition among professional football clubs is irrational, irresponsible and unsustainable, and the sports economics literature is split about on this issue. ${ }^{15}$ Furthermore, even if inherence is accepted, the financial fair play rules also need to be proportional. To establish proportionality would require two things. Firstly, the restrictive effects (for instance, on player salaries) must be proportionate to the legitimate objectives. Obviously, this implies that more restrictive effects require more important objectives. Secondly, it needs to be demonstrated that there is no less restrictive possibility to achieve the objectives. In this context, this particularly would ask for an option achieving the objectives without restrictive effects, for instance, on player wages.

Even so, the financial fair play rules might still be exempt from the law on the grounds that the competitive benefits for the clubs will outweigh the potential harms. In order to do so, financial fair play rules must improve the production or distribution of the goods in question or promote innovation while awarding consumers with a fair share of these benefits. Furthermore, these benefits must be specific to the rules and must not be achievable otherwise. Even if these conditions are fulfilled, an exemption can only be granted if competition is not significantly impeded. While it may be argued that FFP through the no overdue payables rule may

\footnotetext{
${ }^{14}$ The stated objectives are (UEFA 2012: 2):

a) to improve the economic and financial capability of the clubs, increasing their transparency and credibility;

b) to place the necessary importance on the protection of creditors and to ensure that clubs settle their liabilities with players, social/tax authorities and other clubs punctually;

c) to introduce more discipline and rationality in club football finances;

d) to encourage clubs to operate on the basis of their own revenues;

e) to encourage responsible spending for the long-term benefit of football;

f) to protect the long-term viability and sustainability of European club football.
}

${ }^{15}$ It is clear that most football clubs in Europe, in contrast with the counterparts in US major league sports, do not make money, and accounting losses can be substantial. However, it is also a longstanding view that football clubs are not profit maximizers and may be characterized as utility maximizers (Sloane 1971) or win maximizers (Kesenne 1996), both of which might be consistent with persistent accounting losses. To the extent that football club ownership brings prestige then accounting losses may be offset by both pecuniary benefits (e.g. cross marketing of products and services) and non-pecuniary benefits (glamour, prestige, etc). While there are those who argue that loss making in an unregulated football market is both an equilibrium phenomenon and harmful (e.g. Franck 2013), there is equally a counter-view that loss making is both sustainable and a contributory factor in the international success of European football (e.g. Szymanski 2014). 
improve the production of the good by preventing mid-season insolvencies disturbing the league competition, it might be much more difficult to establish a promotion of innovation given the restrictions on innovative investments (focus of the breakeven rule on football-based income). Establishing a consumer benefit may also be difficult if the restrictive effect on player salaries leads to loss of talent to competitions outside Europe. Furthermore, the specificity condition requires demonstrating that there is no other, less restrictive way of achieving the benefits of FFP, i.e. preventing mid-season insolvencies. Eventually, even if all the criteria are fulfilled, granting an exemption would depend on whether the Commission (or the Court) views the restrictions on clubs' investments as being a significant impediment of competition or not. ${ }^{16}$

Now, what about our second story, the "incumbent versus the upstart" effect? In the horizontal view, the clubs form a cartel that advantages some of the cartel members (incumbents) at the expense of others (upstarts). While this is certainly not the typical case with cartel arrangements, it still may be a possibility if the power asymmetries along the pyramid structure favor the interests of the incumbents, i.e. the big front-running clubs in the European competitions. An obvious counter-argument, however, is that the big incumbent clubs represent a minority of votes within the pyramidal structure and can be outvoted by a coalition of the smaller clubs. As an example, consider the issue of release of players to represent the national team. In US sports the major league teams in sports such as basketball and ice hockey have often been reluctant to release the best players for Olympic competition and have limited their participation in international representative competition. ${ }^{17}$ In football the players on the national teams are almost entirely supplied by the largest clubs which are unable to restrict the participation of their players, and this has often been a source of conflict between national associations and big clubs. This problem, generally known as the "club versus country" debate, usually surfaces at the time of major international tournaments such as the World Cup. ${ }^{18}$ A significant portion of the revenues from these competitions is paid out the national associations who then spend the money on development activities that tend to benefit the mass of smaller clubs rather than the big clubs.

The balance of power does not entirely favor the upstarts. The incumbents are able to use their wealth and wider capabilities to lobby for causes that reflect their interests. Consequently, the power relations within football associations in Europe are complex. Nevertheless, we will argue below that the mechanism which favors the influence of the incumbent clubs raises doubt as to whether the horizontal view is appropriate. But at the very least, it may be quite difficult to rationalize the anticompetitive story successfully under the horizontal view. If it can be convincingly advanced, then the same defenses as in the player salary story hold, i.e. legitimate

\footnotetext{
${ }^{16}$ Lindholm (2010: 211) and Long (2012: 96-100) provide such an analysis, concluding that FFP does not qualify for an antitrust exemption according to the conditions of Article 101 (3) TFEU.

17 See e.g. http://www.nytimes.com/2012/07/29/sports/olympics/nba-reassesses-its-olympic-involvement.html? pagewanted $=1$

${ }_{18}$ See e.g. http://www.businessofsoccer.com/2013/09/08/club-vs-country-injury-compensation-andthe-club-protection-program/.
} 
objective, inherence, proportionality, Article 101 (3) defenses. The only difference to the reasoning above would be that proportionality would here require to show that there is a way to combat overinvestment without deterring sugar-daddy-sponsored upstart clubs.

In summary, the horizontal view does offer an avenue to view financial fair play as being in line with competition law. However, such reasoning is not self-explanatory and would require a serious economics-based analysis. The EC's competition commission does not appear to have initially undertaken a critical and thorough competition policy review of UEFA's financial fair play regulations. Instead, commissioner Joaquín Almunia issued a joint statement with UEFA president Michel Platini, embracing the FFP initiative and providing rather uncritical support of it (Almunia \& Platini 2012, Almunia 2012). However, the Commission was forced to enter a more detailed analysis by a formal complaint lodged by Daniel Striani, a Belgium player agent, in May 2013. ${ }^{19}$ Furthermore, Striani and his lawyer, Jean-Louis Dupont (who once brought the famous Bosman case) also directly brought a case against FFP (more specifically, its break-even rule) to the European Court of Justice in June 2013. ${ }^{20}$

Striani and Dupont are concerned with expected restrictive effects on player salaries ${ }^{21}$ and view financial fair play as a cartel among the undertakings hiring players. In order to be successful, Striani and Dupont need to raise sufficient doubt about either the inherence of the financial fair play rules to the stated objectives or the proportionality of the rules in the light of possible alternatives that would not harm players salaries (Lindholm 2010: 208-211).

\section{(c) A Critical View on the Horizontal Approach}

However, while a form-based approach may conclude that there is a horizontal relationship arising from the indirect chain of owner- or memberships leading from the competitors (clubs) to the association, a closer look from an effects-based perspective reveals some problems of the horizontal story. From an economic point of view, the horizontal view should be accurate insofar as the members of the league that is affected by a rule also effectively control the actions of the rule-making sports association. However, what if there are factors that render a control of the sports association by the league members impossible even if there is an indirect chain of memberships? If we stick to the example of the UEFA Champions League, then two effects considerably hamper the control of UEFA by the participating clubs.

- Principal-agent-problems: associations (the agents) act independent from interests of the clubs (the principal) due to a lack of effective control mechanisms. Control may be exercised to some degree at the lowest level, but through the chain of the pyramid of associations, the agents become more

\footnotetext{
${ }^{19}$ See e.g. http://www.financialfairplay.co.uk/latest-news/legal-challenge-to-uefa-ffp-rules-bybosman-lawyer.

20 See e.g. http://www.financialfairplay.co.uk/latest-news/further-legal-challenge-to-ffp-by-strianiand-dupont.

${ }^{21}$ As a player agent, Striani's revenues at least partly depend on player salaries.
} 
and more independent of the principal. Thus, higher-level associations like UEFA are able to pursue other goals than the ones of the principal (clubs), honorable ones like the interest of the sport but also less honorable ones like the personal interests of the officials acting within these associations (career concerns, income, prestige, empire building, etc.). Furthermore, stakeholders (fans, sponsors, politicians, etc.) with diverging interests from the clubs (the principal) may exert a considerable influence on association decisions.

- Broad membership: traditionally, the sports associations have all the clubs as members, not only top-level, professionally-competing clubs but also all amateur, lower-level and grassroots clubs. More often than not, voting rights do not depend on sporting performance but on criteria like the number of club members or equality considerations. Thus, the actual participants of the Champions League represent only a small minority of the "shareholders" of the regional or national associations and, thus, their influence on the composition of the articulated goals of "the" principal (= group of all clubs) is rather small. Moreover, a serious divergence of interests between champions-leaguecompeting clubs and, say, grassroots clubs seems likely.

- On the other hand, the fact that lobbying can influence the decisions of the association may also work into the favor of the larger professional clubs. The economic importance of leading clubs may hand them informal but direct influence on UEFA, giving their interests an excessive weight through the pyramid chain of associations. This may particularly privilege a few clubs which due to their global reputation enjoy an outstanding importance for the prestige of the Champions League as a whole (like Real Madrid, etc.) - and not to all participants of the Champions League. Thus, a conservative bias favoring incumbent 'superstar' clubs may characterize this lobby influence channel.

As a consequence, the league members that are hit by a regulation like FFP may not have the capacity to control UEFA's decisions, even if they have some voting powers. Therefore, the horizontal view may be inappropriate from an effects-based perspective as far as membership-based associations like UEFA are concerned.

\section{The Vertical View}

\section{(a) A Vertical Relationship?}

The first question we should address is whether a regulation imposed by a governing body on some or all of its members can be considered a vertical restraint from the perspective of competition law. Since governing bodies are limited to regulating amateur sport in the US, and since the integrated nature of governing bodies is seen to be a pillar of the so-called "European model of sport", this issue is of far greater relevance to the competition law of the European Union than the US. For our analysis we rely heavily on the European Commission's Guidelines on Vertical Restraints published in 2010. According to the guidelines a vertical restraint can be defined as "an agreement or concerted practice entered into between two or more undertakings each of which operates, for the purposes of the agreement or the concerted practice, at a different level of the production or distribution chain, and relating to the conditions under which the parties may purchase, sell or resell certain goods or services". 
Thus clearly we need to define the different levels of production. For the case of the UEFA Champions League or UEFA Europa Cup, entry into which is governed, inter alia, by the FFP regulations, UEFA clearly stands in the role of a competition organizer. It decides the rules of entry, sets the rules of the competition, provides the matches official, organizes disciplinary procedures and dope testing, manages the draw, schedule the dates and locations of games, ${ }^{22}$ makes sure that stadiums comply with UEFA standards, sells both broadcasting and sponsorship rights and manages the relationships with these parties, determines the allocation of revenues including the prize money which it pays out to clubs (sometimes withholding payment if UEFA regulations are not complied with). UEFA also retains a substantial portion of the revenues to pay for its own administration, and distributes money to its member associations.

The role of the clubs in the competition is largely just to turn up and play. For away matches this requires co-ordination with UEFA in terms of agreeing transport arrangement and organizing training facilities. For home games the clubs keep their own revenues from the ticketing and merchandising, and have to manage their own stadium, while complying with UEFA standards and granting a ticket allocation for hospitality purposes. In exceptional cases (mostly the less important games of the Europa League) which are not of interest to broadcasters contracted under the collective deal, a club may sell its own rights- though typically these will have little economic value. The Final for UEFA competitions is typically awarded to a stadium in Europe through a process of competitive bidding, and so generally neither of the competing teams has any organizational responsibility. ${ }^{23}$

Thus it seems that "competition organizing services" provided by UEFA can be clearly distinguished from "football match-playing services" which are delivered by the participating clubs. In that sense UEFA can be understood as the upstream firm that controls access to an attractive product, seeking to contract with downstream service suppliers. Unlike a product such as cars or beer, UEFA viewed as an upstream firm does not have a finished product; however, that seems little different from the case of an upstream firm that produces an intermediate good.

\section{(b) Is There a Competition Concern?}

The guidelines further state that "[f]or most vertical restraints, competition concerns can only arise if there is insufficient competition at one or more levels of trade, that is, if there is some degree of market power at the level of the supplier or the buyer or at both levels." UEFA by its nature possesses a good deal of market power as the governing body of European football. There are no currently existing rival football

\footnotetext{
${ }^{22}$ While teams play in their home stadiums for all rounds except the final, scheduling is planned to optimize audiences (e.g. so that where possible teams from the same country do not play at the same time) and to avoid potential security risk (e.g. if two or more teams from the same city participate in the competition, then their home games will be scheduled on different days to avoid policing problem).

${ }^{23}$ Although by coincidence it can happen that the Final is awarded to a stadium in which one of the competing teams play- e.g. in 2012 the Champions League Final was held at the Allianz Stadium in Munich, which also happens to be the home stadium of Bayern Munich, who qualified for the Final in that season.
} 
organizations in Europe to which Champions League participant clubs could turn if they were dissatisfied with the structure of the Champions League. However, this does not mean they are powerless - the clubs could create their own independent competition while remaining within UEFA, and indeed have threatened to do exactly that on several occasions, but the costs of implementing this threat would be considerable. The breakaway clubs would face considerable political pressure, while there is the strong possibility that UEFA would continue to schedule its own competition, possibly head-to-head, and so undermine the viability of this strategy. Experience of rival competitions to the US major leagues trying to enter the market is that head-to-head competition is nasty, brutish and short, and the ultimate outcome is almost always victory for the incumbent (see e.g. Quirk \& Fort 1992).

Thus competition organizing services in team sports tend to have the characteristics of a natural monopoly or essential facility, in the sense that it is ideal to have only one competition which determines the identity of the very best team. For example, a rival to the FIFA World Cup would arguably create confusion about the best national football team in the world. Likewise at the domestic club level, two national leagues containing different teams and each claiming to represent the best league competition in the country would tend to fragment the sport. In some sports, such as boxing, rival governing bodies have emerged, each claiming to designate a world champion, and this is often associated with a loss of interest in the sport. At the highest level, interest in sport is heightened by knowing that the best are playing against the best. Thus the position of a governing body such as UEFA is not only dominant, but may actually need to be dominant in order to provide the best possible competition organizing services. ${ }^{24}$

In that sense UEFA clearly enjoys considerable market power vis-a-vis the clubs that compete in its competition. Likewise it has substantial market power vis-a-vis the broadcasters who bid for the rights. There is no alternative to international club competition within Europe, and competition among the top European clubs is highly attractive- games involving, say, Bayern Munich and Barcelona, Manchester United and Real Madrid, represent some of the most watched games, not just in Europe but around the world. It is possible for these clubs to stage friendly games, usually outside of the regular season, and these games are popular, but because they lack the

\footnotetext{
${ }^{24}$ Some scholars, such as Ross (1989), have argued that monopoly (major) leagues in the US should be broken up into competing entities. These competing leagues could be complemented by some sort of play-off between the champions of the competing championships. On this view it might be argued that allowing competition in competition organizing services might also be optimal. Thus it might be suggested that UEFA's governance functions (rule setting, enforcement and discipline) might be separated as a natural monopoly from the potentially competitive competition organizing services business. One potential attraction of this approach is that it might enable potential competitors to overcome artificial barriers. For example, Luxembourg, with a population of around 500,000 is one of the wealthiest regions in Europe (average income around $\$ 80,000$ ) but has no significant football club because football is organized on national territories and the country is too small to sustain a league containing clubs that could be internationally competitive. This barrier would be overcome if a new competition organizer, following the American model, offered the chance to create a Luxembourgeois franchise. Note, however, that the only way for sustained competition to exist would be for antitrust enforcement to be sufficiently active and credible to prevent predation and block mergers (Ross 2003a, 2003b).
} 
sporting significance generated by a competitive championship context, they do not represent close substitutes. ${ }^{25}$

If it is not easy for the big clubs to break away from UEFA, they are still able to act collectively to influence UEFA and the rules of the competition. This is mainly because UEFA's broadcast and sponsorship revenues depend to a significant extent on the big, popular clubs, without whom the UEFA competitions would be substantially diminished. In the past these clubs lobbied openly through the now defunct G14 lobby group, and their voices remain the loudest. However, the established clubs have faced significant entry threats from new rivals, in the form of the so-called "sugar daddies" - wealthy individuals who have injected large sums of money into acquiring playing talent so as to be competitive at the highest level. So far most sugar daddies have been associated with Russian oligarchs (e.g. Roman Abramovitch at Chelsea or Dmitry Rybolovlev at Monaco) or oil sheikhs (Sheikh Mansour at Manchester City or the Qatar Investment Authority at Paris Saint-Germain). In the face of entry from these deep-pocketed competitors, the large incumbent clubs may have an incentive to persuade UEFA to impose restraints on entry of this type.

\section{(c) What Harm?}

Vertical restraints come in many shapes and sizes, including inter alia

- resale price restrictions,

- exclusivity in territories, supply or customer allocation,

- franchising,

- tying, and

- access payments.

It has long been noted by economists that these types of restraint can have positive economic benefits for customers if they result in a higher level of service and enhance inter-brand competition, even if it limits intra-brand competition. The restraints imposed by UEFA on clubs entering its competition, and FFP in particular, can be interpreted as a kind of franchising agreement which specifies minimum service standards and business practices for clubs in UEFA competition. Given that UEFA enjoys a dominant and incontestable position on the upstream market stage competition organizing services, what does that imply for our two anticompetitive stories?

Firstly, with respect to the salary restriction effect, the vertical view would imply that either

- the stage of competition organizing services (UEFA) and match playing services (the clubs) collude to exploit the market for talent (vertical agreement) or

- UEFA has a direct interest in limiting player salaries (and merely uses the clubs' investment behavior as a channel to achieve it) (abuse of dominance).

\footnotetext{
${ }^{25}$ Additionally, there are no gaps in the football calendar, as organized by the governing bodies, which would provide an opportunity for developing a new contest.
} 
If the anticompetitive harm consists of an exploitation of players by employing the market dominance of UEFA on the market for competition organizing services in order to enhance the profits of both this and the vertically-related market stage of the clubs, then it would fall under article 101 (vertical cartel arrangement). Basically, it would require demonstrating that the two colluding market stages can better increase their profits at the expense of the players in a common action than UEFA could alone. The critical aspect here would be the question why UEFA should benefit from restricting player salaries. ${ }^{26}$ This problem becomes even more critical if the salary restriction effect is viewed to result from an abuse of dominance by UEFA. In consequence, it appears to be rather difficult to reason the purpose of a salary restriction effect from a vertical perspective. Then again, it does not require intention from an effects-based perspective: if player salaries decrease as an unintended consequence of FFP, this still represents a restraint.

Secondly, with respect to the incumbent versus upstart effect, the vertical view may imply an anticompetitive foreclosure effect. If the foreclosure consists of trying to keep out entrants, then it would be necessary to establish why UEFA has an incentive to do so. If this incentive is rooted in successful lobbying by the incumbent top clubs, then it would fall under article 101 (vertical cartel arrangement with horizontal effects on the downstream market). Effectively, this would mirror the horizontal approach to this problem (see section 3 ) and probably treated as a horizontal restraint. However, if UEFA itself benefits from restricting and deterring sugar-daddy type of entrants, then article 102 (abuse of dominance by the monopoly association) is addressed. These benefits may consist of reputation effects and superstar rents. Protecting the incumbent superstar clubs may be more profitable for UEFA since they have stronger brands and more marketing potential (at least in the short-run) then the upstart teams. Mainly due to their glorious history, clubs like Real Madrid, FC Barcelona, Manchester United, Inter Milano, Bayern München, etc. enjoy much larger fan bases than comparatively newer players on the top level like Manchester City (and even more so than upstarts that may challenge in the future). In other words, the audience drawing capability of the superstar clubs is significantly higher than those of the other clubs. Consequently, their participation in, for instance, the UEFA Champions League boosts fan interest and, thus, also viewing figures, making the product Champions League more valuable and allowing UEFA to increase revenues (inter alia, from selling broadcasting rights and marketing the brand Champions League). In summary, UEFA may have a distinctively economic interest in cementing the competitive advantage of the incumbent superstar clubs vis-à-vis financially potent upstarts and new challengers by enforcing a rule that future investment levels depend on recent success (= football-related revenues) and outlawing catching-up investments financed by external sources.

In addition to our two anticompetitive stories, the vertical view points at a third anticompetitive story, namely FFP as a means to cementing and strengthening the dominant position of UEFA on the market stage for competition organizing services. If FFP raises the profitability of clubs operating within the Champions League this makes it less attractive for a competing competition organizer (e.g. a broadcaster) to

\footnotetext{
${ }^{26}$ If there is no benefit for UEFA (and only for the clubs), then we are effectively back to a horizontal cartel case (see section 3).
} 
enter the market and compete with UEFA. By cementing their monopoly position on the market stage of competition organizing services, UEFA also increases its power over upstream and downstream markets, inter alia, enhancing its possibilities to reap rents from equipment supply or match playing services in future contract negotiations. If foreclosure is about keeping out rival competition organizers then it would fall under article 102 (abuse of dominance by the monopoly association vis-à-vis the downstream firms (the clubs)).

In all cases, virtually the same defenses as discussed in the preceding section (legitimate objectives, inherence, proportionality) apply. The Article 101 (3) defense, however, only applies in the case of a vertical agreement.

\section{(d) Reflection on the Vertical View}

The vertical view clearly requires us to decide on the desirability of competing championships/leagues, organized by competing associations. If they are desirable, then a focus of competition policy interventions into sports should be on preventing foreclosure towards entry of alternative championship organizers (the FIA case provides a good example for such a focus). If a monopoly is desirable at this stage of the supply-chain, then the focus of intervention should be on protecting upstream and downstream "firms" (as well as customers/consumers) from being abused and on protecting competition on upstream markets (e.g. exclusive contracts with compound/equipment producers like the producer of the football or competition shoes or tyres for racecars, etc.) as well as on downstream markets (e.g. the competition among club owners, players, sponsors, etc.)

This may be important since the remedies are likely to differ. If the focus is on creating competition at the association level (specifically, the market for competition organizing services), then remedies are needed that will limit the ability of associations to prevent the establishment of competing competitions. Examples of such remedies are (i) the separation of governance and promoter functions, (ii) prohibition of noncompetition clauses for participants. These remedies tend to prevent actions that have effects outside the league or championship in question.

If the focus is on protecting competition in upstream and downstream markets, then remedies "regulate" the behavior of the monopoly association within the league/championship towards those levels, such as prohibiting exclusive supply contracts (or requiring tender procedures and limiting maximum contract length) or blocking rules that exclude investors and protect the incumbents of top-level sports competition, etc.). In the extreme, it could be argued that there is a need of public regulation of monopoly sports associations.

Our purpose in this article is not to take a stand on this issue, but simply to point out that the assessment of harm and of remedies, from the vertical perspective, depends on whether the market for sports competition authorities (sports associations), understood as an upstream market or input market, represents a contestable market or not. 


\section{Conclusion}

The horizontal and the vertical view differ with respect to the role of the sports authority, in our case, the UEFA. While the horizontal approach views UEFA as an agent of the - actual and potential - participants of European football club competitions, the vertical approach views the UEFA as a powerful undertaking enjoying a dominant position on one stage of the supply-chain (competition organizing services) and acting largely independent from the clubs. This distinction is important because it creates different types of antitrust cases. Take, for instance, the concern that FFP merely is an instrument to cement the competitiveness of the incumbent clubs vis-à-vis an increasing influx of sugar daddies-financed upstarts. In order to establish a theory of harm, the horizontal view would need to argue that the incumbents cartelize to keep the upstarts out and that the upstarts are forced to join the cartel because of power asymmetries within UEFA and its member associations that favor the incumbents. In contrast, the vertical view would need to establish why it is in UEFA's self-interest to consolidate the market structure of the downstream market for match playing services by reducing competitive pressure from upstarts at that stage of the supplychain. Or take the concern that players' salaries options are limited by FFP. A horizontal theory of harm requires showing that the (actual and potential) clubs seek to lessen their competition for talent by competitive over-bidding (effectively a price cartel on the demand side). The vertical view, in contrast, would need to establish why it is in UEFA's self-interest to limit the prices on the market for talent.

Thus, the theories of harm that need to be tested depend on whether the horizontal or the vertical view is taken with considerable effects on whether a theory of harm can successfully be established or not. We do not want to decide this point here since it would require a serious economics-based analysis. However, at first sight, it seems more promising to establish a theory of harm regarding the player salaries by taking the horizontal view, whereas a theory of harm regarding the deterrence of upstarts may be facilitated by the vertical view.

Furthermore, the competition policy consequences and remedies are likely to differ. While the horizontal view would address the club level as the cause of the anticompetitive restriction, the vertical view would address - solely - the UEFA (the associations level) for remedies and sanctions. Looking beyond FFP, the vertical view would moreover tend to increase Article 102-cases (abuse of dominance), whereas the horizontal view would focus on Article 101-cases (horizontal agreements).

Our purpose in this paper is not to provide a definite answer what view is more appropriate. In particular, we discuss the two views from an economic perspective in the sense that we look at whether a sports association (UEFA) is effectively controlled by the league participants (the clubs) or not. We have not analyzed in detail the legal consequences and possibilities of that question when it comes to indirect chains of memberships. We have not even tried to determine whether the two approaches are mutually exclusive. However, we do want to point out that a thorough reflection of the economic nature of restrictive rules by sports associations - horizontal or vertical in nature - matters for the competition policy analysis and assessment. 


\section{References}

Almunia, J. (2012), Letter to Michel Platini, http://ec.europa.eu/competition/sectors/sports/letter_almunia_en.pdf.

Almunia, J. \& Platini, M. (2012), Joint Statement, http://ec.europa.eu/competition/sectors/sports/joint_statement_en.pdf.

Budzinski, O. (2012), The Institutional Framework for Doing Sports Business: Principles of EU Competition Policy in Sports Markets, in: International Journal of Sport Management and Marketing, 11(1-2), 44-72.

Budzinski, O. (2014), The Competition Economics of Financial Fair Play, in: O. Budzinski \& A. Feddersen (eds.), Contemporary Research in Sports Economics: Proceedings of the $5^{\text {th }}$ ESEA Conference, Frankfurt a.M.: Lang, forthcoming.

European Commission (2007), The White Paper on Sport, COM (2007) 391 final, Brussels.

Franck, E. (2013), Financial Fair Play in European Club Football - What Is It All About? No. 328, UZH Business Paper Working Series, University of Zurich.

Hoehn, T. \& Szymanski, S. (1999), The Americanization of European Football, in: Economic Policy, 14, 203-240.

Kesenne, S. (1996), League Management in Professional Sports with Win Maximizing Clubs, in: European Journal of Sports Management, 2, 14-22.

Kienapfel, P. \& Stein, A. (2007), The Application of Articles 81 and 82 EC in the Sport Sector, in: Competition Policy Newsletter, No. 3, 6-14.

Lindholm, J. (2010), The Problem with Salary Caps under European Union Law: The Case against Financial Fair Play, in: Texas Review of Entertainment \& Sports Law, 12(2), 189-213.

Long, C. R. (2012), Promoting Competition or Preventing it? A Competition Law Analysis of UEFA's Financial Fair Play Rules, in: Marquette Sports Law Review, 23(1), 75-101.

Madden, P. (2012), Welfare Consequences of "Financial Fair Play" in a Sports League with Benefactor Club Owners, in: Journal of Sports Economics, online first, doi:10.1177/1527002512465759.

Maxcy, J. (2014), The American View on Financial Fair Play, in: O. Budzinski \& A. Feddersen (eds.), Contemporary Research in Sports Economics: Proceedings of the $5^{\text {th }}$ ESEA Conference, Frankfurt a.M.: Lang, forthcoming.

Peeters, T. \& Szymanski, S. (2014), Financial Fair Play in European Football, in: Economic Policy, forthcoming.

Quirk J. \& Fort, R. (1992), Pay Dirt: The Business of Professional Team Sports, Princeton N.J.: Princeton University Press.

Ross, S. F. (1989), Monopoly Sports Leagues, in: Minnesota Law Review, 73(3), 643761.

Ross, S. F. (2003a), Antitrust, Professional Sports, and the Public Interest, in: Journal of Sports Economics, 4(4), 318-331. 
Ross, S. F. (2003b), Competition Law as a Constraint on Monopolistic Exploitation by Sports Leagues and Clubs, in: Oxford Review of Economic Policy, 19(4), 569584.

Sass, M. (2012), Long-term Competitive Balance under UEFA Financial Fair Play Regulations, Working Paper No. 5/2012, Otto von Guericke University Magdeburg.

Sloane, P. (1971), The Economics of Professional Football: The Football Club as a Utility Maximiser, in: Scottish Journal of Political Economy, 17, 121-146.

Szymanski, S. (2003), The Economic Design of Sporting Contests, in: Journal of Economic Literature, XLI, 1137-1187.

Szymanski, S. (2014), Fair Is Foul: A Critical Analysis of UEFA Financial Fair Play.

Szymanski, S. \& Zimbalist, A. (2005), National Pastime: How Americans Play Baseball and the Rest of the World Plays Soccer, Washington: Brookings Institution.

UEFA (2008), Here To Stay: Club Licensing, Nyon: UEFA.

UEFA (2012), UEFA Club Licensing and Financial Fair Play Regulations, Edition 2012, Nyon: UEFA.

Vöpel, H. (2011), Do We Really Need Financial Fair Play in European Club Football? An Economic Analysis, in: CESifo DICE Report, 9 (3), 54-60.

Weatherill, S. (2006), Anti-doping Revisited - the Demise of the Rule of 'Purely Sporting Interest'? in: European Competition Law Review, 27, 645-657.

Contemporary Research in Sports Economics - Proceedings of the $5^{\text {th }}$ ESEA Conference

Oliver Budzinski \& Arne Feddersen (eds.)

Frankfurt a.M.: Lang International Publishers 2014 (May/June).

Prolog

1. Introduction (Oliver Budzinski \& Arne Feddersen)

Financial Fair Play in European Football

2. Financial Fair Play: Winners and Losers on and off the Pitch (Thomas Peeters \& Stefan Szymanski)

3. Financial Fair Play - Why Loss-Making Is a Problem: The Example of the English Football League (Sean Hamil)

4. The American View on Financial Fair Play (Joel Maxcy) 
5. The Competition Economics of Financial Fair Play (Oliver Budzinski)

6. Socio-economic Doping and Enhancement in Sport: A Case-based Analysis of Dynamics and Structural Similarities (Thomas Könecke \& Mathias Schubert)

Performance and Competition in International Football

7. In Urgent Need of Change? Within-season Coach Dismissals, Regression-to-themean, and Performance of Football Teams (Nikolaus Beck \& Mark Meyer)

8. Competitive Balance and Attention Level Effects: Theoretical Considerations and Preliminary Evidence (Tim Pawlowski \& Oliver Budzinski)

9. Spill-overs? Economic Progress, Football Facilities and the 2011 Asia Cup (Peter Ochieng)

New Research on Individual Sports

10. Analysis of Event Visitors' Expenditure Patterns: The Case of the Three FIS Ski Jumping World Cup Events 2013 (Grzegorz Kwiatkowski \& Ove Oklevik)

11. Public Opinion on Doping in Cycling: Differences among Population Groups (Daam van Reeth \& Wim Lagae)

12. The Economics of Motorsport Centers (Anika Müller \& Oliver Budzinski)

The Economics of Sports Events

13. The Winner's Curse in Sports Economics (Wladimir Andreff)

14. Sports on the Air: A GARCH Examination of the Impact of Broadcasts of Live Sporting Events on Television Audience Sizes (José Baños, Levi Pérez, Victor Puente \& Plácido Rodríguez)

15. Gridiron Games: A Case Analysis of Turf War Issues and the Economic, Social, Cultural, and Political Incentives for Government Subsidization (Christopher $M$. Keshock, Brooke Forester \& Shelley Holden)

\section{Epilogue}

16. A Survey of Five Years of ESEA Conferences (Daam van Reeth) 


\section{Diskussionspapiere aus dem Institut für Volkswirtschaftslehre der Technischen Universität IImenau}

Nr. 30 Steinrücken, Torsten: Die Legitimation staatlicher Aktivität durch vertragstheoretische Argumente: Anmerkungen zur Kritik an der Theorie des Gesellschaftsvertrages, März 2003.

Nr. 31 Steinrücken, Torsten; Jaenichen, Sebastian: Heterogene Standortqualitäten und Signalstrategien: Ansiedlungsprämien, Werbung und kommunale Leuchtturmpolitik, April 2003.

Nr. 32 Steinrücken, Torsten: Funktioniert ,fairer' Handel? Ökonomische Überlegungen zum alternativen Handel mit Kaffee, Juli 2003.

Nr. 33 Steinrücken, Torsten; Jaenichen, Sebastian: Die Wiederentdeckung der Zweitwohnsitzsteuer durch die Kommunen - zu Wirkungen und Legitimation aus ökonomischer Sicht, September 2003.

Nr. 34 Rissiek, Jörg; Kressel, Joachim: New Purchasing \& Supply Chain Strategies in the Maintenance, Repair and Overhaul Industry for Commercial Aircraft, September 2003.

Nr. 35 Steinrücken, Torsten; Jaenichen, Sebastian: Europäische Beihilfekontrolle und Public Utilities - Eine Analyse am Beispiel öffentlicher Vorleistungen für den Luftverkehr, Dezember 2003.

Nr. 36 Voigt, Eva; GET UP: Gründungsbereitschaft und Gründungsqualifizierung - Ergebnisse der Studentenbefragung an der TU Ilmenau, April 2004.

Nr. 37 Steinrücken, Torsten; Jaenichen, Sebastian: Levelling the playing field durch staatliche Beihilfen bei differierender Unternehmensmobilität, Mai 2004.

Nr. 38 Steinrücken, Torsten; Jaenichen, Sebastian: Sekundärwirkungen von Unternehmensansiedlungen - Eine Beurteilung staatlicher Aktivität beim Auftreten paretorelevanter Nettoexternalitäten, Juni 2004.

Nr. 39 Kallfaß, Hermann H.: Wettbewerb auf Märkten für Krankenhausdienstleistungen - eine kritische Bestandsaufnahme, Juni 2004.

Nr. 40 Engelmann, Sabine: Internationale Transfers und wohlfahrtsminderndes Wachstum, September 2004.

Nr. 41 Steinrücken, Torsten; Jaenichen, Sebastian: Zum Einfluss von Ausländern auf die Wirtschaftsleistung von Standorten - Ist Zuwanderung ein Weg aus der ostdeutschen Lethargie?, Oktober 2004. 
Nr. 42 Steinrücken, Torsten; Jaenichen, Sebastian: Wer ist wirklich reich? - Zu Problemen der Wohlfahrtsmessung durch das Bruttoinlandsprodukt, April 2005.

Nr. 43 Steinrücken, Torsten; Jaenichen, Sebastian: Wo bleiben die Subventionssteuern? - Probleme des Beihilfenrechts und ein alternatives Regulierungskonzept, Mai 2005.

Nr. 44 Jaenichen, Sebastian; Steinrücken, Torsten; Schneider, Lutz: Zu den ökonomischen Wirkungen gesetzlicher Feiertage - Eine Diskussion unter besonderer Berücksichtigung der Arbeitszeitpolitik, Juni 2005.

Nr. 45 Kuchinke, Björn A.: Qualitätswettbewerb zwischen deutschen Akutkrankenhäusern unter besonderer Berücksichtigung von DRG und Budgets, Juni 2005.

Nr. 46 Kuchinke, Björn A.; Walterscheid, Heike: Wo steht der Osten? Eine ökonomische Analyse anhand von Wohlfahrts- und Happinessindikatoren, Juni 2005.

Nr. 47 Kuchinke, Björn A.; Schubert, Jens M.: Staatliche Zahlungen an Krankenhäuser: Eine juristische und ökonomische Einschätzung nach Altmark Trans und der Entscheidung der Kommission vom 13.7.2005, August 2005.

Nr. 48 Steinrücken, Torsten; Jaenichen, Sebastian: Überkapazitäten zur Absicherung politischer Risiken und Instrumente finanzwirtschaftlicher Gegensteuerung, November 2005.

Nr.49 Jaenichen, Sebastian; Steinrücken, Torsten: Opel, Thüringen und das Kaspische Meer, Januar 2006.

Nr. 50 Kallfaß, Hermann H.: Räumlicher Wettbewerb zwischen Allgemeinen Krankenhäusern, Februar 2006.

Nr. 51 Sickmann, Jörn: Airport Slot Allocation, März 2006.

Nr. 52 Kallfaß, Hermann H.; Kuchinke, Björn A.: Die räumliche Marktabgrenzung bei Zusammenschlüssen von Krankenhäusern in den USA und in Deutschland: Eine wettbewerbsökonomische Analyse, April 2006.

Nr. 53 Bamberger, Eva; Bielig, Andreas: Mehr Beschäftigung mittels weniger Kündigungsschutz? Ökonomische Analyse der Vereinbarungen des Koalitionsvertrages vom 11. 11. 2005, Juni 2006.

Nr. 54 Jaenichen, Sebastian; Steinrücken, Torsten: Zur Ökonomik von Steuergeschenken - Der Zeitverlauf als Erklärungsansatz für die effektive steuerliche Belastung, Dezember 2006. 
Nr. 55 Jaenichen, Sebastian; Steinrücken, Torsten: Wirkt eine Preisregulierung nur auf den Preis? Anmerkungen zu den Wirkungen einer Preisregulierung auf das Werbevolumen, Mai 2007.

Nr. 56 Kuchinke, B. A.; Sauerland, D.; Wübker, A.: Determinanten der Wartezeit auf einen Behandlungstermin in deutschen Krankenhäusern - Ergebnisse einer Auswertung neuer Daten, Februar 2008.

Nr. 57 Wegehenkel, Lothar; Walterscheid, Heike: Rechtsstruktur und Evolution von Wirtschaftssystemen - Pfadabhängigkeit in Richtung Zentralisierung?, Februar 2008.

Nr. 58 Steinrücken, Torsten; Jaenichen, Sebastian: Regulierung und Wohlfahrt in einem Modell mit zwei Aktionsparametern, März 2008.

Nr. 59 Lehnert, Ninja M.: Externe Kosten des Luftverkehrs - Ein Überblick über den aktuellen Stand der Diskussion, April 2008.

Nr. 60 Walterscheid, Heike: Reformbedarf etablierter Demokratien im Kontext dezentralisierter Gesellschaftssysteme - Grundlegende Hindernisse bei Steuersystemreformen", April 2010.

Nr. 61 Walterscheid, Heike; Wegehenkel, Lothar: Kostenstruktur, Zahlungsbereitschaft und das Angebot von Mediengütern auf Medienmärkten, Juni 2008.

Nr. 62 Walterscheid, Heike; Wegehenkel, Lothar: Wohlstand der Nationen und handlungsrechtliche Struktur eines Gesellschaftssystems, September 2008.

Nr. 63 Dewenter, Ralf; Haucap, Justus; Wenzel, Tobias: Indirect Network Effects with Two Salop Circles: The Example oft the Music Industry, Juni 2009.

Nr. 64 Dewenter, Ralf; Jaschinski, Thomas; Wiese, Nadine: Wettbewerbliche Auswirkungen eines nichtneutralen Internets, Juli 2009.

Nr. 65 Dewenter, Ralf; Haucap, Justus; Kuchinke, Björn A.: Das Glück und Unglück von Studierenden aus Ost- und Westdeutschland: Ergebnisse einer Befragung in Ilmenau, Bochum und Hamburg, Oktober 2009.

Nr. 66 Kuchinke, Björn A.; Zerth, Jürgen; Wiese, Nadine: Spatial Competition between Health Care Providers: Effects of Standardization, Oktober 2009.

Nr. 67 Itzenplitz, Anja; Seifferth-Schmidt, Nicole: Warum Klimakonferenzen scheitern, aber dennoch zum Wohl des Weltklimas kooperiert wird, Juli 2010. 
Nr. 68 Kallfaß, Hermann H.: Die Aufmerksamkeit für, die Nutzung der und die Werbung in Medien in Deutschland, November 2010.

Nr. 69 Budzinski, Oliver: Empirische Ex-Post Evaluation von wettbewerbspolitischen Entscheidungen: Methodische Anmerkungen, Januar 2012.

Nr. 70 Budzinski, Oliver: The Institutional Framework for Doing Sports Business: Principles of EU Competition Policy in Sports Markets, January 2012.

Nr. 71 Budzinski, Oliver; Monostori, Katalin: Intellectual Property Rights and the WTO, April 2012.

Nr. 72 Budzinski, Oliver: International Antitrust Institutions, Juli 2012.

Nr. 73 Lindstädt, Nadine; Budzinski, Oliver: Newspaper vs. Online Advertising - Is There a Niche for Newspapers in Modern Advertising Markets?

Nr. 74 Budzinski, Oliver; Lindstädt, Nadine: Newspaper and Internet Display Advertising - Co-Existence or Substitution?, Juli 2012b.

Nr. 75 Budzinski, Oliver: Impact Evaluation of Merger Control Decisions, August 2012.

Nr.76 Budzinski, Oliver; Kuchinke, Björn A.: Deal or No Deal? Consensual Arrangements as an Instrument of European Competition Policy, August 2012.

Nr. 77 Pawlowski, Tim, Budzinski, Oliver: The (Monetary) Value of Competitive Balance for Sport Consumers, Oktober 2012.

Nr. 78 Budzinski, Oliver: Würde eine unabhängige europäische Wettbewerbsbehörde eine bessere Wettbewerbspolitik machen?, November 2012.

Nr. 79 Budzinski, Oliver; Monostori, Katalin; Pannicke, Julia: Der Schutz geistiger Eigentumsrechte in der Welthandelsorganisation - Urheberrechte im TRIPS Abkommen und die digitale Herausforderung, November 2012.

Nr. 80 Beigi, Maryam H. A.; Budzinski, Oliver: On the Use of Event Studies to Evaluate Economic Policy Decisions: A Note of Caution, Dezember 2012.

Nr. 81 Budzinski, Oliver; Beigi, Maryam H. A.: Competition Policy Agendas for Industrializing Countries, Mai 2013.

Nr. 82 Budzinski, Oliver; Müller, Anika: Finanzregulierung und internationale Wettbewerbsfähigkeit: der Fall Deutsche Bundesliga, Mai 2013.

Nr. 83 Doose, Anna Maria: Methods for Calculating Cartel Damages: A Survey, Dezember 2013. 
Nr. 84 Pawlowski, Tim; Budzinski, Oliver: Competitive Balance and Attention Level Effects: Theore-tical Considerations and Preliminary Evidence, März 2014.

Nr. 85 Budzinski, Oliver: The Competition Economics of Financial Fair Play, März 2014. 